〈原 著〉

\author{
Japan Surveillance for Infection Prevention and Healthcare Epidemiology \\ （J-SIPHE）による抗菌薬使用量集計の評価
丹羽 隆 ${ }^{1,2}$ ・ 伊藤 朱里 ${ }^{1,2)}$ ・藤林 彩里 ${ }^{1,2)}$ ・鈴木 景子 ${ }^{1,2}$ ・ 米玉利 準 ${ }^{2}$
丹羽麻由美 ${ }^{2)} \cdot$ 太田 浩敏 ${ }^{2)} \cdot$ 土屋麻由美 ${ }^{2)} \cdot$ 伊藤由起子 ${ }^{2)} \cdot$ 畠山大二郎 ${ }^{2)}$ \\ 馬場 $\quad$ 尚志 ${ }^{2)} \cdot$ 村上 啓雄 ${ }^{2)}$
}

\title{
Evaluation of the Antimicrobial Consumption Calculated Using the Japan Surveillance for Infection Prevention and Healthcare Epidemiology (J-SIPHE) System
}

\author{
Takashi NiwA ${ }^{1,2)}$, Syuri Ito ${ }^{1,2)}$, Ayasa Fujibayashi ${ }^{1,2)}$, Keiko SuzUki ${ }^{1,2)}$, Jun YONETAmari ${ }^{2)}$, \\ Ayumi Niwa ${ }^{2)}$, Hirotoshi OHTA ${ }^{2)}$, Mayumi TsuchiYA ${ }^{2)}$, Yukiko ITO ${ }^{2)}$, Daijiro Hatakeyama ${ }^{2)}$, \\ Hisashi $\mathrm{BABA}^{2)}$ and Nobuo MURAKAMI ${ }^{2)}$ \\ ${ }^{1)}$ Department of Pharmacy, Gifu University Hospital, ${ }^{2)}$ Center for Nutrition Support \& Infection Control, Gifu University Hospital
}

(2019 年 8 月 15 日受付 $\cdot 2019$ 年 10 月 15 日受理)

\begin{abstract}
要 旨
Japan Surveillance for Infection Prevention and Healthcare Epidemiology（J-SIPHE）では, レ セプト請求データである入院 $\mathrm{EF}$ 統合ファイルに基づき抗菌薬使用量が集計される。 入院 $\mathrm{EF}$ 統合 ファイルには, 歯科診療, 自由診療等に関する診療のデータが含まれないため, 必然的に実使用量 との乘離が生じる，両者の差異を明らかにするため, 自施設の 2018 年 4 月から 2018 年 12 月の抗 菌薬使用量について, 実使用量に基づいた集計值と J-SIPHEによる集計値とを比較した. Antimicrobial use density (AUD) では, 15 薬剤のうち 14 薬剤 (93.3\%) で両者の差は中央值 10\% 以内 であったが，ピペラシリンではJ-SIPHEによる集計值が中央值で $30.5 \%$ 高值となった. Days of therapy（DOT）では，86.7\% で両者の差は中央值 10\% 以内であったが，アンピシリンでは実使用 量よりも中央值で $29.0 \%$ 低值となった. AUD/DOTでも, ピペラシリンで $33.5 \%$, アンピシリン で $28.2 \%$, それぞれ実使用量より高值となった。 ピペラシリンは小児科での使用, アンピシリンは 歯科での使用が多かったことが影響したと考えられた。J-SIPHEによる抗菌薬使用量の評価では, 実使用量との差異の把握が重要と考えられた。
\end{abstract}

Key words : 抗菌薬, 使用量, 適正使用, Japan Surveillance for Infection Prevention and Healthcare Epidemiology

序文

抗菌薬使用量の監視は, 従来から各医療機関の感染制 御チームにより行われ, 院内の不適正使用を察知すると ともに適正使用の指標のひとつとして使用されてきた. 抗菌薬使用量の集計では, World Health Organization (WHO) が推奨する Anatomical Therapeutic Chemical/ Defined Daily Dose（ATC/DDD）システムを用いる an-

1)岐阜大学医学部附属病院薬剤部, 2) 岐阜大学医学部附属病院生体 支援センター timicrobial use density (AUD) のほか, 投与日数およ び使用患者数の指標となる days of therapy (DOT), 1 日用量の指標となる AUD/DOTによる評価が有用とさ れている1)。しかしながら, DOTは算出に患者毎の実 投与デー夕が必要であるため, 集計が困難な施設も少な くないことが指摘されている2.

2016 年に厚生労働省が発表した薬剂耐性（AMR）対 策アクションプランは 6 分野にわかれており, それぞれ に目標が設定されている．そのうちの 1 つ「動向調査・ 監視」では, 目標として「薬剂耐性および抗微生物剤の 
使用量を継続的に監視し, 薬剤耐性の変化や拡大の予兆 を的確に把握する」ことが挙げられている ${ }^{3)}$. その一環 として厚生労働省委託事業 AMR 臨床リファレンスセン ターが主体となり, 感染対策連携共通プラットフォーム Japan Surveillance for Infection Prevention and Healthcare Epidemiology（J-SIPHE）が開発され，2019 年 4 月から稼働している4). J-SIPHEでは, 手指衛生の実施 状況や微生物 - 耐性菌検出状況等に加えて, 抗菌薬使用 量も収集される. J-SIPHEでは, レセプト請求データで ある入院 $\mathrm{EF}$ 統合ファイルを取り込むことで抗菌薬使用 量が自動集計され, AUD, DOT, AUD/DOTを算出で きる.このシステムを用いることで, 集計が困難な施設 も多いDOTを含め, 簡便に各医療機関で抗菌薬使用量 を集計でき，より詳細な使用量の分析が可能となる．た だし, 集計に使用する入院 $\mathrm{EF}$ 統合ファイルは, 歯科診 療, 自由診療, 労働災害等に関するデータが含まれない ため ${ }^{5)}$, 必然的にJ-SIPHEを利用し集計した抗菌薬使用 量と実使用量に基づく集計との間には差異が生じる.

本研究では, 当院での従来からの実使用量に基づいた 集計と入院 $\mathrm{EF}$ 統合ファイルに基づいたJ-SIPHEによ る集計との差異を明らかにするため, 両集計法による集 計值を比較した。

\section{材料と方法}

\section{1. 施設概要}

当院は 614 床を有する国立大学病院であり, 平成 30 年度の 1 日平均入院患者数は 500 人, 平均在院日数は 11.9 日である。

\section{2. 調査期間および調査対象}

調査期間は 2018 年 4 月から 2018 年 12 月とした。当 院が採用している注射用抗菌薬のうち, 汎用される薬剤 を各系統から 1 種類以上になるよう 15 種類を抽出し対 象とした。

\section{3. 抗菌薬使用量の集計}

$\mathrm{EF}$ 統合ファイル（医科点数表に基づく出来高点数情 報）は, 診療明細情報である E ファイルと行為明細情 報であるFファイルを医事課で統合して作成した，作 成した入院 $\mathrm{EF}$ 統合ファイルから抗菌薬に関連する情報 のみを自動で抽出できるデスクトップアプリケーション Antimicrobial Consumption Aggregate System （ACAS）を用いてJ-SIPHE連携ファイルを作成し，そ れをJ-SIPHEに取り込み抗菌薬使用量を自動的に集計 した。

抗菌薬の実使用量は, 電子カルテから実施量データを 抽出して AUD, DOT, AUD/DOTを集計した。 AUD (DDDs/100 patient-days) は（抗菌薬使用量/DDD） $\times$ 100/入院患者延べ在院日数により算出し, DOT (DOTs/ 100 patient-days）は抗菌薬延べ投与日数 $\times 100 /$ 入院患
者延べ在院日数によりそれぞれ 1 ケ月ごとに算出した. なお DDDは, J-SIPHEが使用しているWHO の ATC/ DDD index version 20196) を用いた。

J-SIPHE による集計と実使用量による集計との差 (\%) は，実使用量による集計を基準として，(J-SIPHEによ る集計－実使用量による集計）/実使用量による集計 $\times$ 100 により算出した.

\section{4. 歯科, 小児科の抗菌薬使用人数}

J-SIPHE による集計と実使用量との間に差異が生じや すい診療科として，入院 $\mathrm{EF}$ 統合ファイルに診療内容が 含まれない歯科および 1 回投与量が少なく残余薬剤の破 棄が生じやすい小児科に注目し, 各薬剤の使用例のうち 歯科および小児科での使用人数を集計した。 なお使用人 数は, 各薬剤の使用例について患者番号を基に集計した ものであり, 同一抗菌薬を複数回投与した例も 1 例とし て計算した。

\section{5. 倫理的配慮}

本研究を実施するに当たっては, 岐阜大学大学院医学 系研究科倫理審査委員会の承認（承認番号：2019-084） を取得した。

\section{結果}

1. 実使用量と J-SIPHE による集計との AUD の乘離 AUDについて，1 ケ月毎に実使用量と J-SIPHEによ る集計とを比較した結果, 調査した 15 薬剤のうち 14 薬 剂（93.3\%）で乘離幅が中央值で 10\% 以内であった（表 1). 一方, ピペラシリンは大きく乘離し, J-SIPHE で 集計した AUD が，実使用量と比較して 30.5(28.2-38.6)\% 〔中央值（四分位範囲）〕高くなった. また，バンコマイ シン, ダプトマイシン, ボリコナゾールは乘離幅が中央 值で $10 \%$ 以内ではあるものの, 実使用量と比較して高 值となった。

\section{2. 実使用量と J-SIPHE による集計との DOT の乘離}

DOT について，1 ケ月毎に実使用量と J-SIPHEによ る集計とを比較した結果, 15 薬凨のうち 13 薬剤(86.7\%) で乘離幅が中央值で $10 \%$ 以内であった（表 2)．J-SIPHE で集計したDOT が，実使用量と比較し高值となった薬 剤はなく, 最も乘離したのはアンピシリンで, 実使用量 と比較して - 29.0（-36.5- - 25.0）\%と大幅に低值となっ た. セフメタゾールも実使用量と比較して -12.4 (-16.6--9.8) \%と低值となった.

\section{3. 実使用量と J-SIPHEによる集計との AUD/DOT の乘離}

AUD/DOT について，1 ケ月毎に実使用量と J-SIPHE による集計とを比較した結果, 15 薬剤のうち 12 薬剤 （80.0\%）で靟離幅が中央值で 10\% 以内であった（表 3）. J-SIPHE で集計した AUD/DOT が, 実使用量と比較し 低值になった薬剤はなく, 最も乘離したのはピペラシリ 
表 1 実使用量と J-SIPHE による集計の比較（AUD）

\begin{tabular}{lccc}
\hline 注射用抗菌薬・抗真菌薬 & $\begin{array}{c}\text { 実使用量 } \\
\text { (DDDs/100 patient-days) }\end{array}$ & $\begin{array}{c}\text { J-SIPHE } \\
\text { (DDDs/100 patient-days) }\end{array}$ & $\begin{array}{c}\text { J-SIPHE による集計と } \\
\text { 実使用量との差 }(\%)\end{array}$ \\
\hline アンピシリン & $0.20(0.18-0.23)$ & $0.16(0.14-0.19)$ & $-6.4(-10.6--6.0)$ \\
ピペラシリン & $0.02(0.02-0.03)$ & $0.03(0.03-0.04)$ & $30.5(28.2-38.6)$ \\
スルバクタム/アンピシリン & $2.14(2.06-2.27)$ & $2.09(2.00-2.13)$ & $-1.5(-5.4--0.7)$ \\
セファゾリン & $4.26(4.14-4.52)$ & $4.20(4.09-4.52)$ & $-1.5(-2.5-0.4)$ \\
セフメタゾール & $1.20(1.13-1.29)$ & $1.08(0.97-1.19)$ & $-9.0(-13.5--6.1)$ \\
セフトリアキソン & $2.05(1.68-2.50)$ & $2.02(1.80-2.43)$ & $-0.6(-2.1-2.3)$ \\
セフェピム & $1.13(1.11-1.28)$ & $1.11(1.06-1.26)$ & $-4.0(-4.9-0.0)$ \\
メロペネム & $1.56(1.40-1.88)$ & $1.58(1.46-1.86)$ & $0.6(0.1-1.0)$ \\
レボフロキサシン & $0.33(0.25-0.43)$ & $0.33(0.25-0.43)$ & $0.0(0.0-0.0)$ \\
バンコマイシン & $0.27(0.22-0.41)$ & $0.28(0.24-0.41)$ & $4.4(1.7-7.8)$ \\
ダプトマイシン & $0.52(0.42-0.63)$ & $0.60(0.45-0.71)$ & $7.6(4.1-12.4)$ \\
ゲンタマイシン & $0.03(0.01-0.04)$ & $0.01(0.00-0.04)$ & $0.0(-27.2-3.1)$ \\
クリンダマイシン & $0.19(0.12-0.22)$ & $0.20(0.10-0.24)$ & $1.6(-8.9-5.4)$ \\
シカファンギン & $0.60(0.42-0.77)$ & $0.60(0.45-0.77)$ & $0.0(0.0-3.9)$ \\
ボリコナゾール & $0.24(0.05-0.30)$ & $0.28(0.05-0.35)$ & $4.0(0.0-18.2)$ \\
\hline
\end{tabular}

值は 1 ヶ月毎に算出した数値の中央值 (四分位範囲).

表 2 実使用量とJ-SIPHE による集計の比較（DOT）

\begin{tabular}{lccr}
\hline 注射用抗菌薬・抗真菌薬 & $\begin{array}{c}\text { 実使用量 } \\
\text { (DOTs/100 patient-days) }\end{array}$ & $\begin{array}{c}\text { J-SIPHE } \\
\text { (DOTs/100 patient-days) }\end{array}$ & $\begin{array}{r}\text { J-SIPHEによる集計と } \\
\text { 実使用量との差 }(\%)\end{array}$ \\
\hline アンピシリン & $0.38(0.33-0.41)$ & $0.22(0.20-0.29)$ & $-29.0(-36.5--25.0)$ \\
ピペラシリン & $0.31(0.30-0.33)$ & $0.31(0.30-0.33)$ & $0.0(-1.7-0.0)$ \\
スルバクタム/アンピシリン & $2.95(2.82-3.02)$ & $2.88(2.78-2.92)$ & $-3.0(-3.5--1.5)$ \\
セファゾリン & $5.73(5.59-6.16)$ & $5.52(5.44-5.81)$ & $-3.8(-4.3--3.4)$ \\
セフメタゾール & $2.02(1.86-2.22)$ & $1.73(1.62-1.98)$ & $-12.4(-16.6--9.8)$ \\
セフトリアキソン & $2.15(1.73-2.44)$ & $2.09(1.73-2.31)$ & $-2.6(-3.8-0.0)$ \\
セフェピム & $1.59(1.55-1.76)$ & $1.53(1.43-1.58)$ & $-3.6(-5.1-0.0)$ \\
メロペネム & $2.20(1.94-2.66)$ & $2.20(1.94-2.64)$ & $0.0(0.0--0.0)$ \\
レボフロキサシン & $0.34(0.29-0.45)$ & $0.34(0.29-0.45)$ & $0.0(0.0-0.0)$ \\
バンコマイシン & $0.42(0.37-0.51)$ & $0.42(0.37-0.51)$ & $0.0(0.0-0.0)$ \\
ダプトマイシン & $0.45(0.33-0.51)$ & $0.45(0.33-0.51)$ & $0.0(0.0-0.0)$ \\
ゲンタマイシン & $0.12(0.10-0.18)$ & $0.11(0.08-0.15)$ & $-2.9(-17.2-0.0)$ \\
クリンダマイシン & $0.37(0.18-0.40)$ & $0.31(0.15-0.38)$ & $-6.9(-8.3-1.3)$ \\
ミカファンギン & $0.54(0.45-0.84)$ & $0.54(0.45-0.84)$ & $0.0(0.0-0.0)$ \\
ボリコナゾール & $0.28(0.05-0.39)$ & $0.28(0.05-0.39)$ & $0.0(0.0-0.0)$ \\
\hline
\end{tabular}

值は 1 ヶ月毎に算出した数值の中央値（四分位範囲).

ンで，実使用量と比較して 33.5 (28.2-38.6) \%高くなっ た.アンピシリンも実使用量と比較して 28.2(25.3-35.4)\% 高值となった。

\section{4. 歯科および小児科における抗菌薬使用が両集計の} 乘離に及ぼす影響

実使用量と J-SIPHEによる集計との AUD の乘離が 30.5 (28.2-38.6) \%と最も高かったピペラシリンは, す べてが小児科での使用例であった（表 4, 図 1).

実使用量と J-SIPHEによる集計とのDOT の乘離が -29.0（-36.5- 25.0）\%と最も大きかったアンピシリ ンは, 使用例に占める歯科の割合が $70.9 \%$ と調査した 15 薬剂の中で最も高かった。靟離幅が-12.4（-16.6-
-9.8）\%と次に大きかったセフメタゾールは, 歯科での 使用割合が $21.7 \%$ と調査した薬剤の中で 2 番目に高かっ た。一方，歯科での使用がなかったピペラシリンおよび レボフロキサシンでは, 両者の乘離は $0 \%$ であり, DOT における乘離と歯科の使用割合との間に関連を認めた。

AUD/DOTは, AUD とDOTの両者の影響を受ける ため，すべて小児科で使用されていたピペラシリンおよ び歯科での使用割合が高かったアンピシリンの 2 薬剤に おいて，実使用量と J-SIPHEによる集計との間に大き な乘離が認められた。 
表 3 実使用量と J-SIPHE による集計の比較（AUD/DOT）

\begin{tabular}{lccc}
\hline \multicolumn{1}{c}{ 注射用抗菌薬・抗真菌薬 } & 実使用量 & J-SIPHE & $\begin{array}{c}\text { J-SIPHEによる集計と } \\
\text { 実使用量との差 }(\%)\end{array}$ \\
\hline アンピシリン & $0.56(0.53-0.57)$ & $0.71(0.64-0.72)$ & $28.2(25.3-35.4)$ \\
ピペラシリン & $0.08(0.07-0.09)$ & $0.10(0.09-0.12)$ & $33.5(28.2-38.6)$ \\
スルバクタム/アンピシリン & $0.73(0.69-0.76)$ & $0.74(0.71-0.75)$ & $0.8(0.7-1.5)$ \\
セファゾリン & $0.73(0.73-0.77)$ & $0.76(0.74-0.78)$ & $2.7(1.6-4.3)$ \\
セフメタゾール & $0.59(0.58-0.61)$ & $0.60(0.60-0.63)$ & $3.2(2.5-3.9)$ \\
セフトリアキソン & $0.97(0.97-1.01)$ & $1.04(0.98-1.05)$ & $2.8(1.6-4.0)$ \\
セフェピム & $0.73(0.70-0.78)$ & $0.73(0.71-0.79)$ & $0.0(-0.2-5.5)$ \\
メロペネム & $0.71(0.67-0.76)$ & $0.72(0.70-0.76)$ & $0.6(0.1-1.0)$ \\
レボフロキサシン & $0.95(0.86-0.96)$ & $0.95(0.87-0.99)$ & $0.0(0.0-0.0)$ \\
バンコマイシン & $0.73(0.57-0.75)$ & $0.75(0.61-0.77)$ & $4.4(1.7-7.8)$ \\
ダプトマイシン & $1.25(1.23-1.30)$ & $1.35(1.25-1.41)$ & $7.6(4.1-13.7)$ \\
ゲンタマイシン & $0.20(0.04-0.23)$ & $0.04(0.04-0.24)$ & $0.0(-16.4-3.1)$ \\
クリンダマイシン & $0.62(0.55-0.70)$ & $0.63(0.61-0.74)$ & $10.5(4.1-12.0)$ \\
ミカファンギン & $0.88(0.84-1.03)$ & $0.88(0.86-1.11)$ & $0.0(0.0-3.9)$ \\
ボリコナゾール & $0.78(0.76-0.88)$ & $0.94(0.80-0.97)$ & $4.0(0.0-18.2)$ \\
\hline
\end{tabular}

值は 1 ヶ月毎に算出した数値の中央值（四分位範囲).

表 4 各薬剤の使用人数に占める歯科, 小児科の割合

\begin{tabular}{lcr}
\hline \multicolumn{1}{c}{ 注射用抗菌薬・抗真菌薬 } & 歯科 $(\%)$ & 小児科 $(\%)$ \\
\hline アンピシリン & $70.9(151 / 213)$ & $11.7(25 / 213)$ \\
ピペラシリン & $0(0 / 57)$ & $100(57 / 57)$ \\
スルバクタム/アンピシリン & $1.1(7 / 640)$ & $3.3(21 / 640)$ \\
セファゾリン & $0.3(7 / 2659)$ & $0.6(16 / 2659)$ \\
セフメタゾール & $21.7(156 / 720)$ & $0.7(5 / 720)$ \\
セフトリアキソン & $2.2(8 / 366)$ & $16.4(60 / 366)$ \\
セフェピム & $1.9(4 / 209)$ & $0.5(1 / 209)$ \\
メロペネム & $0(0 / 301)$ & $6.6(20 / 301)$ \\
レボフロキサシン & $0(0 / 80)$ & $0(0 / 80)$ \\
バンコマイシン & $0(0 / 76)$ & $9.2(7 / 76)$ \\
ダプトマイシン & $0(0 / 28)$ & $3.6(1 / 28)$ \\
ゲンタマイシン & $0(0 / 13)$ & $0(0 / 13)$ \\
クリンダマイシン & $13.3(10 / 75)$ & $13.3(10 / 75)$ \\
ミカファンギン & $0(0 / 52)$ & $9.6(5 / 52)$ \\
ボリコナゾール & $0(0 / 13)$ & $23.1(3 / 13)$ \\
\hline
\end{tabular}

考察

抗菌薬の使用量を正しく評価するためには, 総使用量 に由来する AUD と使用人数拀よび投与日数の指標であ るDOT とを組み合わせることが重要であるが，DOT を算出するには患者毎の実投与デー夕が必要であるため 作業が煩雑であり, 集計困難な施設も少なくない2.7). オー ダリングシステムや電子カルテが導入されていれば, デー夕处理により抽出できる可能性もあるが, 総務省の 平成 27 年度版情報白書によれば，オーダリング導入率, 電子カルテ導入率はともに低いとされている ${ }^{8}$. 一方, レ セプトの電子化率は 2013 年度末の段階で既に医科の $96.6 \%$ に達しており, 大多数の医療施設が完了している. その中のレセプト請求データである $\mathrm{EF}$ 統合ファイルを 用いることで抗菌薬使用量を集計可能な J-SIPHE は, こ
れまで DOT を算出できなかった施設でも質の高い抗菌 薬使用量の評価が可能となる。ささら J-SIPHEによる 集計では手作業をほとんど必要とせず，省力化も可能と する，もちろん，レセプト請求デー夕は，本来分析のた めのデー夕ではなく, 診療報酬請求を目的としたデー夕 であるため ${ }^{9}$ ，実使用量と J-SIPHE による集計との間に は必然的に乘離が生じうるが，その差異を把握したうえ で使用すれば，極めて有用な情報になると期待される.

今回の調查でAUDについては, 調査した 15 薬郕の うちピペラシリンを除く 14 薬剤で実使用量と J-SIPHE による集計の乘離は $10 \%$ 以内に打さまった，AUDによ る使用量集計は既に多くの施設に普及している評価法で あるため, J-SIPHEによる集計と実使用量に基づく集計 との差がわずかであった意義は大きい。ただし，ピペラ 
a. アンピシリン

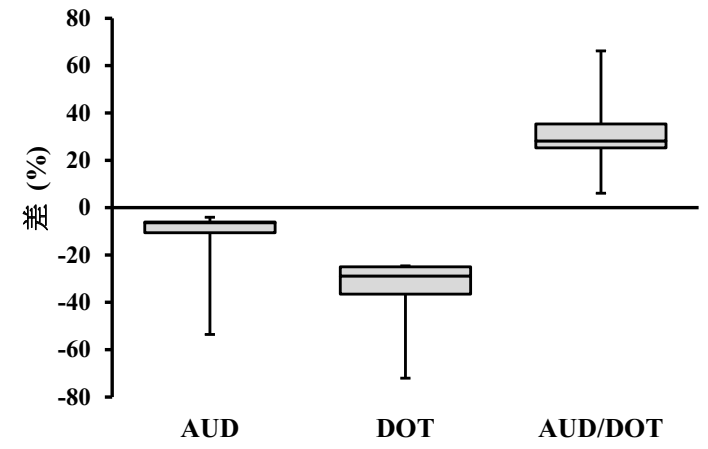

c. ピペラシリン

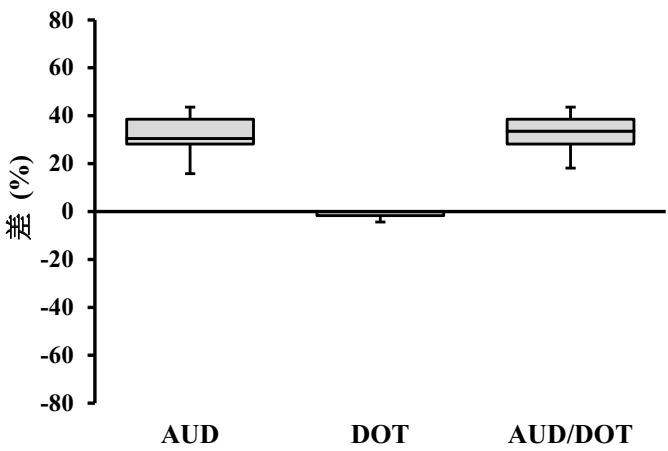

b. セフメタゾール

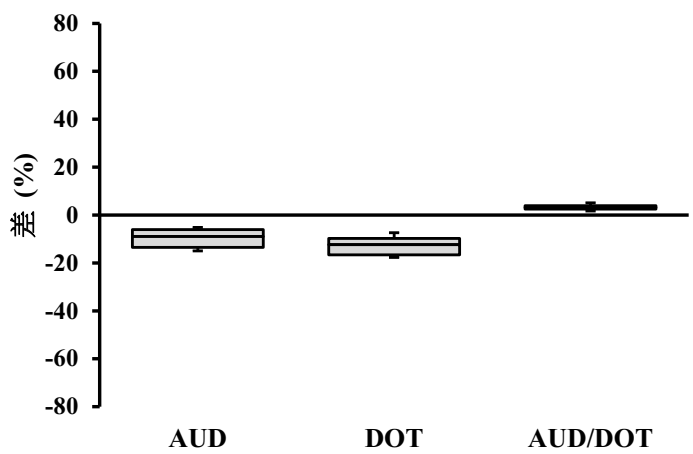

d. レボフロキサシン

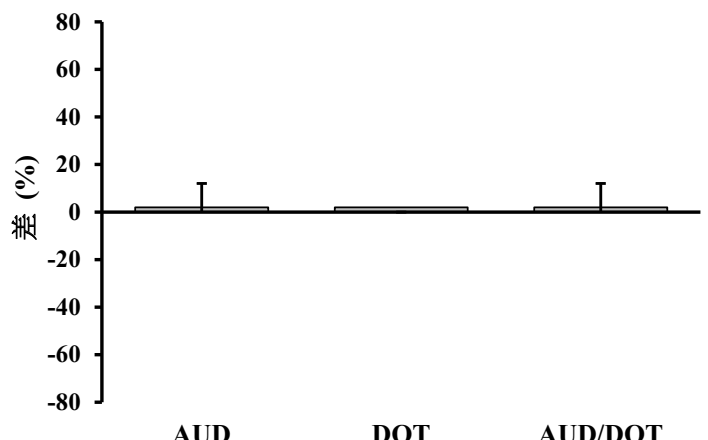

図 1 実使用量とJ-SIPHE による AUD，DOT，AUD/DOT 集計值の差

シリンではJ-SIPHEで集計することにより実使用量と 比較して $30.5 \%$ 高值となった. ピペラシリンはすべて小 児科での使用例であったが，小児科では体重により 1 回 投与量を設定するため残余薬剤の破裹が生じやすく，そ の影響と考えられた。 また，同様に体重により投与量を 設定するバンコマイシン, ダプトマイシン , ボリコナゾー ルも実使用量と比較していずれも高值となり, 残余薬剤 の破衰の影響が考えられた。

DOTについても，15 薬剤中 13 薬剤で実使用量と JSIPHE による集計との乘離幅が $10 \%$ 以内であった。し かしながら，アンピシリンでは $29.0 \%$, セフメタゾール では $12.4 \%$ 低值となるなど, 使用例に占める歯科の割合 が高い薬剤ほど実使用量と J-SIPHEによる集計の差が 大きくなる傾向が認められ， $\mathrm{EF}$ 統合ファイルに含まれ ない歯科における抗菌薬使用が DOT の乘離に影響する ことが示唆された.

AUD/DOT は, AUD およびDOT に大きな乘離がみ られたピペラシリンとアンピシリンの 2 薬剤で, 同じく 大きな乘離を認めた。すなわち, AUDに影響する小児 科での使用割合や, DOT に影響する歯科での使用割合 が，AUD/DOTの乘離にも大きく影響すると考えられ た.

一方，本研究は単施設における検討であるため，いく
つかの限界がある。実使用量と J-SIPHEによる集計と の乘離は，小児科や歯科における使用割合によって大き く影響されるが，各抗菌薬の診療科毎の使用割合は施設 によって異なる。そのため, 他の施設では異なる薬剤で 大きな乘離がみられる可能性がある。また残余薬剤の破 裹が発生しやすい薬郕として, 小児科での抗菌薬使用以 外にも，体重により投与量を設定するダプトマイシンや ボリコナゾール等が挙げられる。本研究では, どちらの 薬剤も, AUD, DOT, AUD/DOTはすべて 10\% 以内 の差であったが，これらの薬剤も施設毎の使用状況や患 者背景によっては一定の影響を受けると推察される。さ らに，本研究では $\mathrm{EF}$ 統合ファイルに含まれない患者と して歯科のみを検討したが, 自由診療や労働災害など同 様に $\mathrm{EF}$ 統合ファイルに含まれない他の患者の影響を検 討していない.いずれにしても, 患者背景など施設によっ て異なる因子も多く，J-SIPHEによる集計を導入する際 には実使用量との差異を施設毎に検証し，把握すること が重要と考える.

結論として, 本研究の中で従来からの抗菌薬の実使用 量に基づなた抗菌薬使用量集計と J-SIPHEによる集計 とを比較した結果, 多くの薬凨では AUD, DOT, AUD/ DOT のいずれの指標も, 10\% 以内の乘離にとどまるこ とが示唆された。ただし， EF 統合ファイルに含まれな 
い歯科等の患者の割合や小児科での使用割合に大きく影 響されることが明らかとなり，施設毎の患者背景の違い などによって乘離する薬剤やその程度が異なることが推 察された，従って，各施設でJ-SIPHEを用いて抗菌薬 使用量の集計および評価を行う際には, 実使用量と JSIPHEによる集計との差異を予め把握しておくことが 重要と考えられた.

謝 辞 : 本論文作成にあたり, 御助言賜りました岐阜大学医学 部附属病院薬剤部 鈴木昭夫 薬剤部長に深謝致します.

利益相反自己申告：申告すべきものなし.

文献

1）丹羽 隆, 外海友規, 鈴木景子, 渡邊珠代, 土屋麻由美, 太 田浩敏, 他 : Defined daily dose (DDD) と days of therapy （DOT）を用いた抗菌薬使用量の評価. 環境感染誌 2014; 29(5): 333-9.

2) 継田雅美：中小病院での抗菌薬適正使用と感染管理におけ る認定薬剤師の活動. 日本化学療法学会雑誌 2017; 65(4): 552-7.

\section{Evaluation of the Antimicrobial Consumption Calculated Using the Japan Surveillance for Infection Prevention and Healthcare Epidemiology (J-SIPHE) System}

\author{
Takashi NiwA ${ }^{1,2)}$, Syuri ITO ${ }^{1,2)}$, Ayasa FujIBAYASHI ${ }^{1,2)}$, Keiko SuZUki ${ }^{1,2)}$, Jun YONETAMARI ${ }^{2)}$,

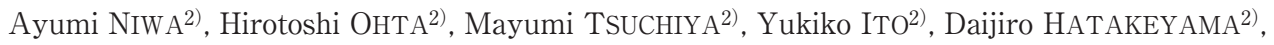 \\ Hisashi BABA $^{2)}$ and Nobuo MURAKAMI ${ }^{2)}$
}

1) Department of Pharmacy, Gifu University Hospital, ${ }^{2)}$ Center for Nutrition Support \& Infection Control, Gifu University Hospital

Abstract

In the Japan Surveillance for Infection Prevention and Healthcare Epidemiology (J-SIPHE) system, antimicrobial consumption was calculated using receipt data for the diagnosis procedure combination (DPC). However, data of dental treatment, private practice, and industrial accidents were not included in the DPC receipt data. Therefore, the antimicrobial consumption calculated using the J-SIPHE system is not completely identical to that calculated by actual administered data, theoretically. In the present study, we compared the antimicrobial consumption data between both methods in our hospital from April 1, 2018 to December 31, 2018. The differences of the values of antimicrobial use density (AUD) between both methods were within $10 \%$ in all the investigated antimicrobials except for piperacillin (PIPC). In PIPC, which was used in pediatrics only in our hospital, a median 30.5\% higher value of AUD was observed using the J-SIPHE method, compared with the actual administered data method. The differences of the values of days of therapy (DOT) between both methods were within 10\% in 13 (86.7\%) of 15 antimicrobials, although the DOT values of ampicillin (ABPC), which was often used in dental treatment, were calculated median $29.0 \%$ lower than that by the J-SIPHE method. Regarding AUD/DOT, the values using the J-SIPHE method were higher than those by the actual administered data method, and those of PIPC and ABPC were calculated median $33.5 \%$ and $28.2 \%$ higher, respectively. These results suggest that it is important to grasp the difference of measured antimicrobial consumption between the J-SIPHE method and the actual administered data method for implementation of the measurement of antimicrobial consumption using the J-SIPHE method.

Key words: antimicrobial agent, consumption, appropriate use, Japan Surveillance for Infection Prevention and Healthcare Epidemiology 